Maria Angeles Ruiz-Moneva1

DOI: $10.31902 /$ LL.2019.7.3

\title{
THE USE OF WHEREAS AND WHEREAS CLAUSES IN SWIFT'S THE DRAPIER'S LETTERS
}

\begin{abstract}
Jonathan Swift (1667-1745) was actively involved in the political affairs of the Ireland of his life-time. Even though he belonged to the higher social classes, namely, the Anglo-Irish ruling minority, he sought to make the whole of the Irish population aware of their economic and political conditions, so that his "Countrymen" or "Fellow-Servants" (as he addressed the whole of the Irish) may pursue to improve their situation. In order to become closer to his intended audience, he decided to use several personae or fictional characters. One of these was the drapier, as the identity chosen in most of the series of seven Letters known as The Drapier's Letters (1724). Although he adopted many colloquial expressions and the register that a shop-keeper would employ, he was fully aware of the legal implications both of the whole issue at large and also of the particular proposals that he was making. This apparent inconsistency was meant to provide the Irish with the tools which he found necessary for them in their struggle to attain better political and economic conditions. It may be hypothesized that one of the aspects illustrating Swift's use of both colloquial language and the legal register is the connector whereas: on the one hand, as a discourse marker with its everyday meanings; on the other hand, with legal senses. The present paper seeks to explore and systematise these uses.

Key words: Swift's The Drapier's Letters, pragmatics, legal English, whereas, whereas clauses, legal implications.
\end{abstract}

\section{Introduction}

The Anglo-Saxon writer Jonathan Swift (1667-1745) undertook a very active role in political affairs in the Ireland of his time. Despite being a member of the higher social classes, he struggled to improve the economic and political conditions of all the Irish, at a time when Ireland was under British sovereignty. With a view to becoming sympathetic and closer to his intended audience, in his production devoted to the Irish Question, he adopted the perspective of several personae or fictional characters. One of these was the drapier, which he used in a series of seven Letters (1724). Most of his political writings came as Swift's response to concrete events. The Drapier's Letters were composed by Swift on the occasion of the grant of a patent that enabled an individual, William Wood, to coin large sums of copper money for Ireland. This metal was going to be used instead of gold or silver, which were the metals commonly used, because at that time the value of money closely depended on the value of the metals employed. This meant, therefore, deleterious consequences for the economy of Ireland. A drapier, that is, a shopkeeper, represented a suitable mask not only to come as close as possible to Swift's intended audience, but to act as a perfect antagonist to a metal-dealer like Wood (Monck Mason, 1820; Temple Scott, 1903/2004; Usandizaga, 1982; Welch 2000; Martin, 2007).

This being so, however, at the same time, Swift struggled to lay clear the foundation of the claims that he put forward and that he believed could be useful in the defence of Ireland. As a matter of fact, some scholars that have undertaken the

${ }^{1}$ Associate professor at the University of Zaragosa (Spain). 
study of these Letters - namely, Temple Scott 2004 (1903) - have shown that Swift must have pursued legal aid, and that he was aware of the legal intricacies of the whole issue, as well as of the proposals that he himself was suggesting. Concretely, Temple Scott remarks that Mr. Robert Lindsay, a Dublin lawyer, is believed to have helped Swift in the writing of this text, and also to have written two letters addressed to Chief Justice Whitshed on the issue of his conduct towards the grand jury that discharged Harding, the printer (1724/2004: 59, footnote n. 23).

It will be hypothesised that one of the aspects that might have been expected to illustrate the coalescence of the legal register with more colloquial uses of language is the use of the discourse marker whereas. The use of this connector within The Drapier's Letters will be studied, and its use will also be explored in other texts of the period that are closely related and entrenched with the matter under consideration. In the Appendix, we have listed the whole series of occurrences of whereas that will be analysed in the paper. The different contexts have been numbered, and will be referred to in the analysis.

After this overall introduction to the main topic dealt with in the paper as well as to the historical context of Swift's The Drapier's Letters, Section One draws on the main theoretical background that will be applied in the study. This concerns two main aspects: first, the grammatical study of the conjunction whereas and also the particular constructions with it employed in legal language; and second, a discussion of the main traits of legal language. It is certain that Swift's The Drapier's Letters is not a legal text. However, it is our contention that the Anglo-Irish author dwelled upon this register in order to substantiate his claims and his attempt to help his "Countrymen" and "Fellow-Servants". This section will particularly focus upon the uses of the so-called whereas clauses in legal language. After these theoretical notes, Section Two corresponds to the main part of the paper and will analyse the use by Swift of both the conjunction whereas and the whereas clauses. Finally, the main conclusions reached in our study will be presented.

\section{Theoretical background}

For the writing of the present paper, two main theoretical contexts have been taken into consideration, together with the literary, cultural, political and socio-historical context where The Drapier's Letters has to be inserted - referred to in the previous section: functional grammar and the study of legal language.

Quirk et al. (1985/1991) note down that whereas is one of the subordinating conjunctions that may introduce only finite clauses. Whereas may connect concessive clauses and also clauses of contrast, which convey this type of relationship between two clauses. It is regarded as a formal sort of conjunction, and it calls for an antithesis or a contrast of some kind between the two situations that it links.

Legal language may be characterised not just by lexical and semantic features. As authors such as Alcaraz (1994/2002), Alcaraz and Hughes (2002, 1993/2003), or Borja Albi (2000) have shown, morphologic, syntactic, discourse and stylistic features are also important to define the way legal texts are constructed. These features will be briefly referred to next, before concentrating upon the so-called whereas clauses. 
Legal English is an extremely peculiar and complex variety of language. From the point of view of its lexical and semantic features, Legal English may generally be characterised by its obscurity (Alcaraz, 2002). The main lexical and semantic features of Legal English have to do with the following aspects (Alcaraz and Hughes, 2002; Alcaraz, 1994): the use of Latinisms; the existence of terms of French or Norman origin; a formal register and an archaic diction; the selection of certain archaic adverbs and prepositional phrases; redundancy, by using doublets and triplets; the frequent appearance of performative verbs and verbs of an empirical meaning; the preference for certain euphemisms instead of more literal expressions; the use of certain colloquial words and phrases; the presence of abbreviated forms of language; the ascription of a semi-technical meaning to certain adjectives when used in a juridical context; or the use of nominalisations.

The language used in law is characterised by "lexical vagueness and syntactic ambiguity" (Alcaraz and Hughes, 2002: 30), which lie at the core of many of the difficulties raised by the interpretation and translation of legal texts. From the point of view of lexis and semantics, vagueness is reflected in the use of certain rhetorical functions, such as definitions; in the relationship between connotation and denotation, and the implications that both may have in the selection of a definite register; in lexical categories such as polysemy, homonymy, synonymity, antonymy, hyperonymity and hyponymy, or false cognates and false friends; and finally in phenomena connected with the use of certain resources of figurative language (Alcaraz and Hughes 2002; Alcaraz 1994).

Following Alcaraz and Hughes (2002) and Alcaraz (1994), as well as Borja Albi (2000), some of the main features of the morphology and syntax of Legal English are summarised next: first, unusually long sentences; second, the anfractuosity of English legal syntax; third, an abundant use of the passive voice, including constructions not frequently found elsewhere; fourth, conditionals and hypothetical formulations; fifth, the simple syntax of plain judicial narrative; sixth, the use of the suffixes -er (or) and -ee to refer to the active and the passive parties in legal relationships; seventh, the frequency of gerundive constructions; eighth, a somehow peculiar use of the conjunction that; ninth, the scarcity of connectors; tenth, the repetition of certain words and syntactic constructions that is avoided in Spanish; eleventh, insufficient and even inadequate punctuation. Other features pointed at by Borja Albi (2000) are the following: the abundant number of nominalisations followed with postmodifications; the use of special determiners with premodification; certain peculiar verbal groups; and the appearance of certain adverbs in initial position as connectors. Another feature, also briefly referred to when speaking about the lexical and semantic archaisms present in legal English, has to do with the use of - th as an ending in the third singular person in the simple present tense, which may also be approached as a morphologic archaism.

More concretely, and directly connected with the issue under study in this paper, the West's Encyclopaedia of American Law notes that the word whereas, as used in legal matters, traces its origin to Middle English. This work also refers to several meanings of this connector which can be used in law: first, it can mean "on the contrary"; second - and more closely associated to the uses that we shall find in

Logos et Littera: Journal of Interdisciplinary Approaches to Text 
the corpus under study - it may be used as the introductory word to a recital in a formal document.

Recitals correspond to the introductory words of certain legal documents, such as contracts, statutes, resolutions or proclamations. For instance, in a contract, whereas clauses are introductory statements with the meaning of "considering that" or "that being the case", so that they explain the reasons why the contract is executed or celebrated, therefore describing its purpose. The West Encyclopaedia also signals that whereas clauses may be used in court orders before those clauses that contain the directions of the court. The content and composition of these whereas clauses will let the public know the reasons why a certain resolution is published.

No matter if they are not actually regarded as essential components of the operative provisions of those legal documents, these whereas clauses may be used for the interpretation or construction of such texts. Each of these clauses should contain a statement of fact logically related to the intent or purpose of the resolution. They may correspond, therefore, to the preamble of the resolution. On the whole, these whereas clauses explain the reasons why this resolution will be adopted and also justify the needs for it.

In the following sections of this essay, the use of whereas and also of whereas clauses in Swift's The Drapier's Letters will be analysed. Possible kinds and meanings conveyed by these constructions will catered for, in both the aspects of the text which are intended for a lay, non-specialised readership, on the one hand, and on the other hand, in those fragments which deal with the legal intricacies of the whole issue, and in whose writing Swift must have sought legal advice. On the whole, it can be expected that both whereas and also whereas clauses will appear in a variety of contexts.

\section{Analysis of whereas and whereas clauses in Swift's The Drapier's Letters and in related works}

We start this section with a note on the corpus selected and the methods applied in this study.

\subsection{A note on the corpus selected for the study and on the method followed}

The corpus that has been used for the analysis has been taken from the critical edition of Swift's The Drapier's Letters signed by Temple Scott (1903/2004) and which, as noted in the reference section, may currently be found at two different Internet websites. For the purposes of the present paper, the selection of the items to be analysed has included not only those samples that actually belong to Swift's The Drapier's Letters. The reason for such a choice is grounded on the fact that in the Appendices of the edition used, several texts which have a close relationship with the matter at stake in Swift's work have been included. These are contemporary to Swift's work, and have to do with original material and historical documents that are being referred to in the Letters. Therefore, they are certainly endowed with unmistakably historical interest, because they enable readers to further contextualise the matter being discussed. Besides, some of these documents have to 
do with legal matters. Consequently, in our view, these texts may offer insights on the use of whereas and whereas clauses at Swift's time, both in legal texts and in other text types. The corpus used compiles the whole of the instances of the use of whereas in both the text of Swift's Drapiers Letters and the appendices referred to in this critical edition.

The list of the utterances that have been used for the analysis has been included as an Appendix to the paper. A somehow larger sample of the context where they appear has been quoted, so that the use and meaning of whereas can be adequately grasped in the corresponding context. Therefore, the corpus includes, on the one hand, samples from those Letters by the Drapier where instances of whereas may be found (either as a conjunction or as part of the so-called whereas clauses of legal texts), namely, Letters II ("To Mr. Harding, the Printer"), III ("To the Nobility and Gentry of the Kingdom of Ireland"), IV ("To the Whole People of Ireland), and V ("A Letter to Lord Chancellor Middleton"), as well as the so-called "Seasonable Advice". On the other hand, the contexts where whereas has been found in the different appendices of this edition have been included, for the reason commented upon above. Concretely, these refer to a report made by Sir Isaac Newton on the composition of Wood's coinage (Quotation 15), letters to the Honourables who had to determine on the issue at stake (16 and 17), the Presentment of the Grand Jury of the County of the City of Dublin (Appendix V), and also the Proclamation against the Drapier (Appendix VI), and finally a fragment of the way in which the case was presented to the Parliament (Appendix VIII). These will be commented upon next.

\subsection{Analysis (I): The Letters. - Letter II: TO MR. HARDING THE PRINTER}

The first instances of the uses of whereas can be traced in Letter II (vid. quotations 1 to 4, in the section APPENDIX: CORPUS OF THE INSTANCES ANALYSED; henceforth, Appendix). This Letter was addressed by the drapier, M.B., to Harding, the printer of the First Letter, and who would eventually undertake to publish the whole of the series of the Letters written by Swift under the persona of the drapier. It has also been regarded by critics as a sort of introduction to the fourth letter of the same series, To the Whole People in Ireland, as well as for a response and preparation of the public mind for the report that the Privy Council - a consultative body formed by prestigious people who undertakes to advise the King of Britain - was about to issue concerning Wood's coinage of copper money. This epistle was published on August 6,1724 , shortly after news appeared in several Dublin papers that the inquiry of Wood's coinage, ordered by a Committee of the Council in London, had found in Wood's favour and would soon be made public in an official report Not only does Swift criticise the assay itself, but he also intends this Letter to counterargue Wood's proposed compromise that no more than $£ 40,000$ of copper would be minted, which Swift regarded as a real threat to the economy and welfare of Ireland.

To begin with, whereas (vid. Q. 1) is used to draw an effective contrast between the speaker himself, under the persona of the drapier, on the one hand, and on the other hand, his antagonist Wood, a metal trader. What is more, the speaker as a shopkeeper has sought to know the opinions of traders and other people. Likewise, instances of the lexis associated with computation can be traced in the work, which will also be a constant, recurrent trait in some other works by Swift on the Irish 
Question. Here, it is interesting to see that this preference for exactness and precision is applied to the number of people actually inhabiting Ireland at the time ("computed to be one million and a half"). Thus, it is important for the speaker to find out the actual requirements for coinage that would be necessary in Ireland. It is to this precise computation of money ("will amount only to five and twenty thousand pounds") that the much larger amount of coinage of copper that Wood must have planned to introduce in Ireland is contrasted against. It is this comparison that is introduced by means of whereas, which in this context has its habitual meaning of the expression of a contrast. Besides the number of people in Ireland ("two hundred and fifty thousand families") is balanced against one single individual, Wood, who is moreover ironically defined as "... whereas this honest liberal hardwareman". Therefore, the word whereas also enhances the ironic characterisation of the Drapier's antagonist and target of his attack. Needless to say, for Swift or the Irish Wood was furthest from being either "honest" or "liberal". The role of irony in Swift's writings has consistently been shown by criticism (e.g., Eilon, 1988; Bullit, 1961).

Soon after, Letter II focuses upon one of the proposals actually made by Wood, who claims to have coined a certain quantity of copper money, which is then harshly criticised by the Drapier (vid. Q.2). This is one of the instances that may be said to embrace a twofold meaning, both signalling contrast and at the same time pointing at a sort of initial situation. Thus, Wood's proposals take into account certain initial conditions, which come under the subordinate clause introduced with the conjunction whereas. In the context, it equals and may have been substituted for by "considering that", or "taking into account that". At the same time, however, the concessive meaning is not really lost. It is altogether clear from context that. On the whole, the meaning intended to be conveyed is that the Drapier makes it clear that Wood has not any intention to stop his trade of coining brass or copper money for Ireland, which means the ruin of the whole country.

A word that recurs in this and in the following passages (vid. Q.3, Q.4) is proposal, and in the two cases it is used to refer to one that has been put forward by Wood, the antagonist of the Drapier and indeed the main target that Swift seeks to criticise in these Letters. For readers familiar with Swift's works - in particular, those connected with "the Irish Question", and even more so with A Modest Proposal (1729) - it will perhaps not be hard to associate those expressions with Swift's 1729 desperate work. Similar words can be found in works by Swift, not only in those dealing with political matters, but also in the Third of the Voyages made by Gulliver, or in A Tale of a Tub: thus, lexical items such as project, projector, undertaker, proposal, or scheme (to name just a few representative instances) are usually endowed with very negative connotations. In general, these have to do with a recurrent topic in Swift's work, as is the criticism of the blind faith in progress and in science, which for the Anglo-Irish author may have led into the neglect of the deleterious consequences that mankind's actions may eventually have.

In this context, therefore, it should not come as a surprise that the patent granted to Wood and the subsequent actions undertaken by him are referred to as "proposals": as a consequence, they are endowed with the most negative kind of connotations and encyclopaedic meaning that may have been expected from Swift. 
What Swift aims to achieve is, then, to arouse the most energic reaction of refusal amongst the whole population of Ireland.

After the reference to Wood's first proposal, a more generic allusion to the whole of the projects put forward by the ironmonger follows, and which Swift, under the persona of the Drapier, seeks to undermine (Q.3). Here, Swift charges his opponent Wood with "perfect high treason". As in many other instances and highly characteristic of Swift's style (Downie, 1984; Ward, 1973; Speck, 1969; Bullit, 1961; Davis, 1964, 1947; Quintana, 1948/1964), a hypothetical-deductive process of reasoning is followed, where Swift makes use of devices such as the logical syllogism, and its rhetorical counterpart, the enthymeme. The conclusion of such a logical and rhetorical reasoning process is introduced by the words "by which it is plain". Here, we find a significant enough use of the term whereas, in so far as it is employed with its more general meaning that denotes contrast, but yet it appears in a context where both reference to legal matters and also the use of other features characteristic of legal texts are not scarce. Thus, in these fragments (Q.2, 3 \& 4) we find the use of archaisms (such as the verbal form hath); the use of the subjunctive mood and of conditional clauses ("unless the exigencies of trade require it"; "if it be offered"), or the use of the modal auxiliary shall with grammatical persons other than the first one, and in order to convey obligation ("He promises, that no person shall be obliged to receive more than fivepence halfpenny of his coin in one payment"). Not only can we find these morphological and syntactic traits characteristic of legal language. The use of technical terms of the legal register can also be traced, in words such as prerogative by law, or claim such a power.

A new reference to the patent that enables Wood to coin copper money for Ireland as a proposal can be found soon after (vid. Q.4). If, on the one hand, we have just seen a profuse employ of terms and constructions characteristic of legal texts; now, on the other hand, we can associate this mention of the patent with expressions that typically recur in many other texts by Swift. This is the case of phrases such as the following: "Perhaps I have been too tedious" - also found in "The Story of the Injured Lady" (Swift, 1707); "melancholy subject", or "humbly offering one proposal" - found in works such as A Modest Proposal (Swift, 1729). Likewise, Swift's mastery of language and also of multiple registers is observed in the polysemic use of the word judicious in his next words: "Let some skilful judicious pen draw up an advertisement to the following purpose". Thus, on the one hand, judicious may refer to what is sensible or reasonable; on the other hand, it is applied to something that is connected or related to law, to legal matters. We feel that in this passage both interpretations may be possible.

This is precisely the context where new instances of the use of whereas may be traced. As a matter of fact, the proposal that Swift (or the Drapier) will put forward next, which will be fully sensible and common-sensical (in contrast to what will happen in A Modest Proposal), will be worded through a series of whereas clauses. In our view, such a listing of whereas clauses imitates the sort of register to be found in certain legal texts, such as resolutions. Thus, Webster's Online Dictionary and West's Encyclopedia of American Law note the following about this use of whereas: 
WHEREAS: considering that; it being the case, since; -- used to introduce a preamble which is the basis of declarations, affirmations, commands, requests, or like, that follow (Webster's). In the law the term whereas also is used as the introductory word to a recital in a formal document. A recital contains words of introduction to a contract, statute, proclamation, or other writing.

The passage found in Q.4 reproduces, therefore, the style of a legal text, through the use of different whereas clauses. It must have been intended to endow the Drapier's statement of the main aspects concerning Wood's case with the precise level of formality. Moreover, it cannot be forgotten that, in writing The Drapier's Letters, Swift purports to achieve the withdrawal of the patent that had been granted to Wood, an objective that he will eventually accomplish. For this reason, he does not hesitate to employ a register - that of legal language - which is indeed one of the most formal registers of the language. And this is so even though, we could say, this breaks or suspends the verisimilitude endowed to the persona of the Drapier, which Swift had devised with a view to reaching his intended readership. However, at the same time, Swift must have intended to furnish his "Countrymen" and "Fellow-Servants" with arguments powerful and valid enough, so that they may eventually achieve to turn down the prerogative that had been conceded to Wood. The proposals put forward by the Drapier, then, resemble the preamble or recitals of a contract. This also demonstrates the Drapier's (and certainly, Swift's) commitment with the task of helping his "Countrymen" and "Fellow-Servants" and furnishing them with suitable arguments to attack Wood's patent.

\subsection{Analysis (II): The Letters. Letter III: "TO THE NOBILITY AND GENTRY OF THE} KINGDOM OF IRELAND"

It may be argued that the intended addressees of Letter III, "To the Nobility and Gentry of the Kingdom of Ireland", surpass those social groups referred to in the title, as the Drapier's claims will embrace the whole nation. Indeed, this Letter contains some of the best-known arguments by Swift addressed to all the Irish: "Were not the people of Ireland born as free as those of England? (...) Am I a freeman in England, and do I become a slave in six hours by crossing the Channel?" (p. 37). Here, we shall find uses of whereas and of whereas clauses both in the body of the "Letter", and also in the notes introduced in connection with it.

The first reference to the patent granted to Wood that reflects the use of whereas is shown in Q. 6. Its everyday, general meaning allows the Drapier to draw a clear contrast between the value of the copper money coined by Wood for Ireland and the value of the money coined in British mints. As critics have noted, this is indeed one of the main issues at stake in the whole controversy: at the time the value of money was directly related to the material in which it was coined. Therefore, it made a whole difference depending on whether it was coined in gold or silver - as was currently being done, and was certainly the case in Britain - or in copper, as Wood purported to do for Ireland.

The fragment quoted in Q.7 deepens precisely into this particular aspect. The arguments of those who oppose Wood's patent are then endowed with legitimacy, in

Logos et Littera: Journal of Interdisciplinary Approaches to Text 
so far as it is the Parliament itself that has come to "represent this grant to be "destructive of trade, and dangerous to the properties of the people»". This may even be more interesting if it is borne in mind that at the time the Irish Parliament was fully dependent on the British: it could not even assemble without the previous permission granted by Britain. It may also be emphasised how Swift - who socially belonged to the upper classes, and, most important of all, was a member of the Anglo-Irish ruling minority, felt the need that Ireland had to overcome its divisions (be they political, social, economic or religious), and indeed undertook the task to struggle for the union of his "Fellow-Servants" and "Countrymen", in most of his political writings.

Furthermore, the discussion has to be set against the context of a contrast that is drawn between the patent granted to Wood, on the one hand, and on the other hand, previous patents that had allowed particular individuals the coinage of money. Swift will reach the conclusion that the system was fully deleterious for the Irish economy, and avowed for an Irish central bank, or a mint where money could be coined. This was one of the most important aspects in which, together with the political submission to the British regime, Ireland had become "a depending kingdom". Wood's patent is, in this context, compared to previous patents that had been allowed to coin money for Ireland. This is the message conveyed through whereas in this context, which therefore retains its everyday meaning, as a way to draw a contrast.

Soon after, Swift (or the Drapier) goes a step further, and in a much more explicit manner than before, his discussion focuses upon the legal intricacies that are involved in the granting of patents to coin money (Q.8). He does so by even questioning the King's authority to grant a patent to an individual, an aspect that he will retake afterwards: his claim - expressed in a form of enthymeme - is that, had the King known or realised that the patent was deleterious for his most loyal servants, the Irish, he would not have allowed such a thing. Indirectly, then, he comes to compromise the King, and makes him ultimately responsible for the situation.

Swift's boldness comes even further, by openly questioning the British legal system as a whole, which, because of the fact that it is based on common law, relies on precedents. Thus, the precedent that Swift makes reference to that situation which might have resembled the current one at his own time occurred at a moment of rebellion against Queen Elizabeth I. The use of whereas enables him to come back to his own time and situation. It is perhaps significant that this time the subordinate clause introduced by it has been somehow isolated from its main clause, in so far as a strong punctuation (colon), has been used, in order to contrast that time, of the sixteenth century, with Swift's own time, of the eighteenth. It is as if Swift were implicitly - and boldly - trying to draw apart the two historical moments, and as if he were attempting to ground his claims on the coinage of money as a means to avoid rebellion against the King. Again, therefore, we find a use of whereas with its commonest meaning of drawing a contrast in a fully legal and political context.

His questioning of the legal system also has consequences in the most immediate context of the Report issued by a committee designated by the Privy Council. This is so because the Privy Council is a consultative organism of the British 
legal system that is formed by barristers and other important advisors, and which may be sitting at the King's request, in order to provide him with advice that may ground and orient his decisions.

The doctrine of the precedents characteristic of the common law that represents one of the main sources of law, together with equity, is then challenged with regard to the differences that Swift and the Drapier see between the patent granted to Wood and previous patents (Q.9). In this sense, it should not be forgotten that the British legal system as a whole relies upon the doctrine of the binding precedent, which is in fact one of its main sources. Only can the ratio decidendi from a court of record create binding precedent. Through this doctrine of binding precedent the decisions made by the higher courts in the hierarchy are bound and compulsory on the courts below them. This is so because consistency is called to play an essential role. What consistency means is that similar cases should be treated alike. Therefore, the decision adopted by a certain court shall be consistent with decisions in previous cases, and at the same time, it will also confer certainty for future cases. This procedure should also provide people with certainty when arranging their affairs, and will make the courts' opinion be regarded as reliable. Even though it is a fundamental pillar of the British legal system, the doctrine of binding precedent is based on the Latin maxim "Stare decesis et non quieta movere". A somehow loose or free translation of the maxim could read as follows: stand by what has been decided and do not unsettle the established. All in all, it means that a decision made in one case is binding on all following cases of similar fact in lower courts (Alcaraz 1994/2002; Poor, 1971). It is likewise interesting to note that the clause introduced by whereas is used with its usual meaning of contrast, even though it appears in a context that deals with the legal implication. Furthermore, it actually raises the main point of the controversy, no matter if it introduces a subordinate clause.

\subsection{Analysis (III): The Letters. Letter IV: "A Letter to the Whole People of Ireland"}

This Letter is interesting in so far as it does not only focus upon the issue of the copper money, but pursues to make the Irish aware of their own condition and situation. Swift wrote it under the persona of the Drapier so that his "Countrymen" and "Fellow-Servants" would become aware of their right to freedom, and would also strive for the consecution of the same rights as the citizens of Britain.

One of the aspects dealt with by the Drapier in this Letter is the discussion and his refusal of the status of Ireland as "a depending kingdom" (Q.12). In this case, the clause introduced by whereas is again enhanced and emphasised, as it actually puts forward the main point upheld by the speaker. It shows, therefore, the counterargument that contradicts such a status, and gives way to the conclusion that Swift must have intended his primary readers to assimilate: "and Ireland is on the contrary called in some statutes an "imperial crown»". Graphically, it is also significant to note that the clause introduced by whereas is preceded and followed by a strong punctuation mark (a semicolon;), so that it is somehow treated as if it were indeed a main clause. Swift's purpose is definitely here to undermine and argue against the status of Ireland as being dependent on England, while he strives

Logos et Littera: Journal of Interdisciplinary Approaches to Text 
to make his target readership aware of the fact that they should struggle to achieve their freedom and independence.

2.5. Analysis (IV): Seasonable Advice to the Grand Jury, Concerning the Bill Preparing Against the Printer of The Drapier's Fourth Letter

The "Seasonable Advice" was published after the Fourth Letter, and because of the fact that the printer of the previous letters, Harding, had been imprisoned. It is addressed to the Grand Jury who has to hear the charges presented against the printer and whose members are lay-people - that is, lacking any specific training in legal matters, following the British legal system. It was devised by Swift with a view to influencing their decision, and indeed he was successful in doing so. Even though it is itself presented unsigned, and is therefore anonymous, anybody familiar not only with the controversy raised around Wood's half-pence, but also with the active role taken by Swift, would have no doubts in ascribing it to him. No matter if a reward of three hundred pounds had been offered, for whomever that might have given Swift away, nobody betrayed him.

Despite the fact that the members of the jury must have been lay-people, as has just been noted, the language used comes close to the register of a legal text. Be it as it may, only one use of whereas has been registered in this piece (Q.13). It is used to draw a contrast between two main groups of people: on the one hand, the members of the jury, who are acting selflessly, and most of whom actually happen to be merchants and shopkeepers, and therefore, may come close to or at least be sympathetic with the drapier's situation; on the other hand, those who seek to influence or even entice them.

\subsection{Analysis (V): The Letters. Letter V: A Letter To The Lord Chancellor Middleton} Letter $\mathrm{V}$ represents the last part of the series of Letters where some use of whereas has been traced. This time, the speaker gives up the perspective of a shopkeeper - as had been recurrent in the previous letters, and refers to himself as "a member" or "a lawyer" (p.68). Just to offer an instance, even in the previous writing, the Seasonable Advice to the Grand Jury, the speaker had endeavoured to identify himself as a shopkeeper and accordingly establish a distance between himself and the members of his class, or even the Jury - formed up by laypeople, on the one hand, and the Lord Justice, on the other hand. Now, he declares to take this perspective in order to speak with the utmost respect and with no purpose of drawing on a controversy: "My Lord, I desire you will consider me as a member who comes in at the latter end of a debate; or as a lawyer who speaks to a cause, when the matter hath been almost exhausted by those who spoke before" (p. 68, my italics). In contrast to the rest of Letters, Letter V, addressed to Lord Middleton, is signed by "J.S.", that is, by Jonathan Swift himself.

No matter if, as has just been seen, the speaker has compared himself to a lawyer, yet only one instance of the use of whereas has been traced, and moreover, it has a clearly concessive meaning (Q.14): thus, despite the existence of "a malicious report", such a report was "false and groundless".

Logos et Littera: Journal of Interdisciplinary Approaches to Text 


\subsection{Analysis (VI): Paratext (I): the Appendices}

The Appendices found in the edition issued by Temple Scott, employed in the present essay, illustrate some of the main aspects that Swift developed in his series of Letters. As before, we have selected those fragments in which some use of whereas has been made. In our view, because of the fact that some fragments actually pertain to legal texts, they may exemplify the use made of whereas in this sort of register at the time.

The first sample (Q. 15) corresponds to a fragment of the Report made by Isaac Newton, Edward Southwell and Thomas Scroope on the composition of the coinage issued by Wood. Such coinage is compared to those issued thanks to previous patents in different moments of history, in the reigns of King Charles II, James II, William III and Queen Mary, respectively. Therefore, whereas is used to draw the contrast between the coinages issued at those moments in history, on the one hand, and Wood's coinage, on the other hand.

The same may be said of Q. 16 and 17, which reproduce some fragments of Letters addressed to "the Right Honourable". The first of these Letters upholds the role of the King, within a historical context, with a view to showing that in contrast to tyrannical princes, clement leaders were never blamed for clemency or for the pious acts that they may have undertaken. Once more, the Drapier intends to get the King involved and even defy and compromise his role.

In the second Letter, the word 'counsel' is explained, so that a contrast is drawn between the counsel of a king, on the one hand, and the counsel of a juror, on the other hand. Thus, even though this aspect of the Letter dwells upon aspects that have a legal application, it is the meaning of contrast contributed by whereas that pervades. Therefore, we find this general meaning of whereas in a legal register or context, so that legal terminology and expressions are used: finding or not finding; sworn to keep secret; Latinisms, such as billa vera or ignoramus, or archaisms of the kind of hereafter.

The last three examples selected from the Appendices - namely, Q. 18 to 20 are taken from texts that may have been regarded as purely legal, and which are related to the whole case or process against the Drapier. These are, namely: "The Presentment of the Grand Jury of the County of the City of Dublin"; the "Proclamation against the Drapier by the Lord-Lieutenant and Council of Ireland"; and, finally, "Ireland's Case Humbly Presented to the Honourable the Knights, Citizens, and Burgesses in Parliament Assembled".

A presentment is defined by the electronic edition of the Merriam-Webster Dictionary consulted in the following terms: "the act of presenting to an authority a formal statement of a matter to be dealt with; specifically: the notice taken or statement made by a grand jury of an offense from their own knowledge without a bill of indictment laid before them". Whereas has been typically used in the manner of that conjunction which puts forward the context where a resolution will be indicted next; and therefore, with a fully legal sense.

The Proclamation reproduces the actual legal document that was issued, in which a reward was offered for that individual that might have been ready to betray the Drapier. Even so, (as shown above) nobody gave Swift away. Moreover, the Proclamation against the Drapier shows other features characteristic of legal texts, 
such as the following: the use of grammatical archaisms (the use of ye instead of the; hath as the verbal form for the third singular person of the simple present of to have); the use of lexical archaic words, such as "intituled"; the use of repetitions, in the form of doublets, of the kind of "printed and published", or "publish and declare"; the use of archaic adverbs and prepositions, such as hereby, hereof, thereby. Shall has been used in the third person, in order to establish an obligation. The punctuation is likewise scarce, in the use of long clauses which are accompanied by plenty of coordination and subordination. Even so, sometimes the punctuation follows rules that are more akin to other Germanic languages, such as German: for instance, a comma has been used before the introduction of a subordinate noun clause introduced by the conjunction that. Finally, some words of everyday use acquire a more specific meaning in the text, as is the case of semi-technical terms used in the legal register. This is the case of the word given, with the meaning of "proclaimed", or "issued".

Very similar features can be appreciated in the fragment corresponding to Q.20, the Presentment of Ireland's Case in Parliament. Whereas is used in order to introduce the premises that will be taken into consideration in order to formulate the declaration that will be proclaimed in the assembly of Parliament. It has, therefore, a legal meaning. Once more, other features of legal texts can be traced, such as the following: the use of long clauses, with plenty of coordination, subordination and embedded clauses; or the use of morphologic and syntactic archaisms, such as sheweth.

\subsection{Analysis (VII): Paratext (II): the Footnotes}

In some of the footnotes of the edition followed, different texts related to the controversy have been included. They reproduce actual documents issued in connection with some particular aspects of the patent granted to Wood. All three footnotes that will be analysed are found in Letter III, "To the Nobility and Gentry of the Kingdom of Ireland".

The first of these documents, reproduced in Q.5, corresponds to a Letter issued by the Archbishop of Dublin. It shows the difficulties that the Parliament of Ireland must have faced in important occasions, even to assemble. This was so because a preliminary authorisation of the Parliament sitting in London was compulsory. In this context, whereas is used to show the contrast between two hypothetical situations, which are differentiated depending on whether the Parliament had been sitting or not.

The second piece, found in Q. 10 (from footnote 15, to Letter III) corresponds to a report commented upon by Monck Mason, author of a History and Antiquities of the Collegiate and Cathedral Church of St. Patrick near Dublin from its Foundation in 1190, to the Year 1819. The argument put forward by this author credits Swift's central claim in his Drapier's Letters that the only coinage accepted was that of gold or silver. If such coinage were not possible, tracking commodities was even found preferable. As a matter of fact, this will be a solution also accepted by Swift. The constructions formed with whereas found in this fragment establish contrasts, either between what was done before and what is currently being done; or between the situation of coinage between England and Britain at the time. This fragment is also

Logos et Littera: Journal of Interdisciplinary Approaches to Text 
interesting because it reflects another of the critical standpoints adopted by Swift throughout the whole of his production devoted to the Irish Question, namely, his harsh criticism of the Irish gentlemen and nobility who preferred to live in England, even though their possessions were mostly in Ireland.

The third fragment, corresponding to Q. 11 (footnote 20, to Letter III), reproduces several advertisements made public by certain tradesmen, who declared to be unrelated to or have nothing to do with Wood's patent for the coinage of copper money for Ireland. In these advertisements, whereas is used in order to show preliminary conditions, premises or hypothetical situations. Once more, in the same contexts, other features of legal texts have been traced, such as the use of performative verbs and also of archaic adverbs and prepositions, as in "do hereby declare"; the use of long clauses and sentences, with a great deal of subordination and embedded clauses. Among such embedded clauses, we have found new instances of the use of subordinate that-clauses that have been preceded and separated from the main clause by means of a comma, as in: "And we do further declare, that we will not directly or indirectly, be anyways concerned with the said Wood's halfpence or farthings;". What is more, even the signers of these texts refer to them as resolutions: "And of this my resolution I gave notice to the person who sent me the bills of lading, (...)".

\section{Results and discussion}

The analysis just carried out may be synthesised in the following table:

\begin{tabular}{|c|c|c|c|}
\hline \multirow[b]{2}{*}{ TEXT } & \multicolumn{3}{|c|}{ USE OF WHEREAS } \\
\hline & Contrast & Legal meaning & Ambiguous \\
\hline Drapier's Letter II & $\begin{array}{c}\text { (Q.1) } \\
\text { (Q.3), in a legal context }\end{array}$ & $(\mathrm{Q} .4)$ & $(\mathrm{Q} .2)$ \\
\hline Drapier's Letter III & $\begin{array}{c}\text { (Q.6) } \\
(\mathrm{Q} .7) \\
\text { (Q.8), in a legal context } \\
\text { (Q.9), in a legal context }\end{array}$ & & \\
\hline Drapier's Letter IV & (Q.12), in a legal context & & \\
\hline Seasonable Advice & (Q.13), in a legal context & & \\
\hline Drapier's Letter V & (Q.14), in a legal context & & \\
\hline Appendix II: Report & $(\mathrm{Q} .15)$ & & \\
\hline Appendix IV: Letter & (Q.16) & & \\
\hline Appendix IV: Second Letter & (Q.17), in a legal context & & \\
\hline $\begin{array}{l}\text { Appendix V: Presentment of the } \\
\text { Grand Jury }\end{array}$ & & (Q.18) & \\
\hline $\begin{array}{l}\text { Appendix VI: Proclamation against } \\
\text { the Drapier }\end{array}$ & & (Q.19) & \\
\hline $\begin{array}{c}\text { Appendix VIII: Ireland's Case } \\
\text { Presented (...) In Parliament (...) }\end{array}$ & & (Q.20) & \\
\hline Footnote 4 to Letter III & (Q.5), in a legal context & & \\
\hline Footnote 15 to Letter III & $\begin{array}{c}\text { (Q.10): } 2 \text { instances of whereas } \\
\text { expressing contrast }\end{array}$ & & \\
\hline $\begin{array}{c}\text { Appendix VIII: Ireland's Case } \\
\text { Presented (...) In Parliament (...) }\end{array}$ & & & \\
\hline Footnote 4 to Letter III & (Q.5), in a legal context & & \\
\hline Footnote 15 to Letter III & $\begin{array}{l}\text { (Q.10): } 2 \text { instances of whereas } \\
\text { expressing contrast }\end{array}$ & & \\
\hline Footnote 20 to Letter III & & $\begin{array}{l}\text { Q.11, footnote 20, } \\
\text { 1st. and 2nd. } \\
\text { advertisements }\end{array}$ & $\begin{array}{c}\text { Footnote } 20 \text { to } \\
\text { Letter III }\end{array}$ \\
\hline
\end{tabular}


The results summarised in the table above show that in the text of Swift's The Drapier's Letters there is a remarkable tendency to use whereas with its meaning of contrast, as is characteristic of general English and everyday prose. We should like to account for this in the following general aspects: it must be borne in mind that, no matter if Swift was dealing with a subject matter that inevitably had legal implications, his intended readership was indeed the common public. Therefore, Swift's main concern was that the message could reach the whole of his intended audience, as he used to say, the whole of the Irish, whom he regarded as and addressed to as his "Countrymen" and "Fellow-Servants". Consequently, he must have assumed that the acquaintance with legal matters of the average, prototypical "Fellow-Servant" was scarce. For this reason, he undertook to explain the whole matter, including its legal implications, in such a manner that his message could be understandable by everybody.

This factor of the intended audience also accounts for the fact that, even in those parts of the text that are addressed to those who may be regarded as "legal subjects", most uses of whereas that have been spotted remain close to its everyday meaning of contrast. In our view, this is so because the members of the jury were lay-people, following the characteristics of the British legal system. What is more, it is said that many of its members were shopkeepers and traders. Therefore, the speaker's intention is make them stand on his side: he does not seek so much to train them in legal matters, as to show them clearly the standpoint that they are expected to uphold.

In our view, another reason that accounts for this pre-eminence of the use of whereas with its everyday meaning of contrast, even in contexts where legal matters are dealt with, may be related to the genre of the texts studied. Thus, it may be noted that, no matter if a topic which has legal implications is being addressed by Swift in his Drapier's Letters, the text cannot really be regarded as legal, strictly speaking. In this sense, it is remarkable to find that whereas has tended to maintain its usual sense of contrast even in some of those contexts where a particular legal aspect or implication has been commented upon.

A further aspect that enhances these results has to do with the comparison with the appendices that have been referred to. These have been the following: the "Presentment of the Grand Jury of the County of the City of Dublin", the "Proclamation against the Drapier" and "Ireland's Case Humbly Presented to the Honourable the Knights, Citizens, and Burgesses in Parliament Assembled". Therefore, these may be regarded as legal or administrative texts. It is in those texts that the instances of whereas with a legal meaning, distinct from its everyday senses, have been traced.

\section{Conclusions}

To sum up the above discussion, let us say that in The Drapier Letters, on the one hand, Swift adopts the persona of a shopkeeper, which enables him to become close to the problems that his intentional or primary addressees had to face. On the other hand, he also sought legal advice and showed himself to be concerned about the legal implications of the claims that he was putting forward. A particular 
consequence is connected with the uses of the word whereas, in so far as this must have meant that we may expect uses of whereas both in legal and everyday English contexts. We have drawn on those uses, with a view to attempting to establish some kind of systematisation. Our preliminary hypothesis pointed at the co-existence of the two main kinds of uses of whereas referred to above - namely, with its everyday meanings, and also with a more specific, legal orientation. The analysis undertaken has confirmed our hypothesis that Swift mastered both sorts of senses, and, depending on the different contexts, he must have used whereas (and, more specifically, also whereas clauses) with a twofold purpose: to come closest to his "Fellow-Servants" and "Countrymen", and also to provide them with legal grounds to uphold their claims against the British.

Even so, the analysis of the corpus has shown a much greater pre-eminence of the use of whereas with those meanings that are normally used in everyday language. In our view, the reason for the relative quantitative scarcity of the legal uses of whereas has to do probably with the fact that we are not dealing with legal texts, strictly speaking. As noted above, however, not only the text types used may account for this preponderance of the general uses of whereas. The speaker's intention as well as the features that characterise the target audience or readership may also shed light on this aspect. Thus, Swift intended above all to raise the rejection of the patent fostered by Wood, and wanted such refusal among his "Countrymen" and "Fellow-Servants" to be as broad as possible.

We have also traced instances of whereas in which this connector, generally with its everyday meaning of contrast, enhances ironic attitudes that Swift sought to arouse. These refer, above all, to his own appraisal as a pretended shopkeeper or Drapier as contrasted to Wood, the metal 'fake' trader who was only concerned about his own interest and did not hesitate about ruining the Irish to achieve his purposes. As for footnotes and appendices, they have been found to allow the reader to trace the chronological evolution of the whole issue, with some of the actual legal and administrative documents released within the whole controversy.

On the whole, the analysis has shown that in The Drapier's Letters, Swift, under the persona of the Dubliner shop-keeper, seems to have been attempting to establish some kind of covenant or contract with his "Countrymen" and "FellowServants". Above all, he has sought to make the Irish, his "Fellow-Servants" and "Countrymen", aware of the situation of oppression that the British exerted upon them, and to make them react against it. As regards the use of whereas, we can perhaps point to a twofold contrast or continua between everyday uses and legal uses of the term, and to the enhancement of either literal or ironic uses. In synthesis, Swift used whereas and whereas clauses as concrete resources to convey his message effectively, and pinpoint the attitudes that he sought to arouse amongst his primary or intended readership.

\section{Acknowledgements}

The research for the writing of the present paper started thanks to a project financed by the Spanish Ministry of Science and Technology, "Jonathan Swift: The translation and dissemination of his work" (BFF 2002-00653), and a research group

Logos et Littera: Journal of Interdisciplinary Approaches to Text 
sponsored by the Government of Aragon, through the research team "SWIFT" H46 (245-132), formed in 2006 and whose activity has continued to the present.

\section{References}

Alcaraz Varó, Enrique. El inglés jurídico. $5^{\text {th }}$ ed. Madrid: Ariel Derecho, 2002 (1994).

Alcaraz, Enrique, and Brian Hughes. Legal Translation Explained. Manchester: St. Jerome, 2002.

Alcaraz Varó, Enrique, and Brian Hughes. Dicionario de términos jurídicos inglésespañol, español-inglés. 7th ed. Madrid: Ariel Derecho, 2003 (1993).

Biber, Douglas. Corpus Linguistics: Investigating Language Structure and Use. $7^{\text {th }}$ ed. Cambridge: Cambridge University Press, 1998.

Birch, Dinah. The Oxford Companion to English Literature. Oxford: Oxford University Press, 2009.

Borja Albi, Anabel. El texto jurídico inglés y su traducción al español. Barcelona: Ariel Lenguas Modernas, 2000.

Bullit, John M. "Satiric Detachment: Invective, Diminution, and Irony". Jonathan Swift and the Anatomy of Satire. A Study of Satiric Technique. Cambridge. Mass.: Harvard University Press, 1961. 38-67.

Cannon, J.A., ed. The Oxford Companion to British History. 2nd ed. Oxford: Oxford University Press, 2009.

Connolly, S. J., ed. The Oxford Companion to Irish History. $2^{\text {nd }}$ ed. Oxford: Oxford University Press, 2007 (2002).

Davis, Herbert. The Satire of Jonathan Swift. London: Macmillan, 1947.

Davis, Herbert. Jonathan Swift: Essays in his Satire and Other Studies. New York: Oxford University Press, 1964.

Downie, J.A. Jonathan Swift. Political Writer. London: Routledge and Kegan Paul, 1984.

Eilon, Daniel. "Swift's Satiric Logic: On Parsimony, Irony, and Antinomian Fiction". The Yearbook of English Studies. Vol. 18, Pope, Swift, and Their Circle Special Number (1988), pp. 18-40.

Martin, Sydney. The Hibernia Coinage of William Wood (1722-1724). Ann Arbor, Mich.: C4 Publications, 2007.

Mason, William Monck. History and Antiquities of the Collegiate and Cathedral Church of St. Patrick near Dublin from its Foundation in 1190, to the Year 1819. Dublin: Folds, 1819. Web 10 July 2020

<https://books.google.es/books/about/The_History_and_Antiquities_of_the_ Colle.html?id=y5ogAQAAMAAJ\&redir_esc=y>

Merriam-Webster's Dictionary Online: Web 10 July 2020 <http://www.merriam-webster.com/dictionary/>

Poor, H. 1971. You and the Law. Pleasantville, New York: R.D.A.

Quintana, Ricardo. "Situational Satire: A Commentary on the Method of Swift". Swift: A Collection of Critical Essays. Ed. Ernest Tuveson. Prentice-Hall: Englewood Cliffs, 1964 (1948): 91-99.

Quintana, Ricardo. Swift: An Introduction. London: Oxford University Press, 1966 (1955).

Logos et Littera: Journal of Interdisciplinary Approaches to Text 
Quirk, Randolph et al. A Comprehensive Grammar of the English Language. London: Longman, 1991 (1985).

Speck, W.A. Swift. London: Evans Bros. Ltd., 1969.

Swift, Jonathan. "The Story of the Injured Lady (Being a True Picture of Scotch Perfidy, Irish Poverty and English Partiality)". Irish Tracts 1720-1723. Ed. Herbert Davis. Oxford: Blackwell, 1968 (1707). 1-9.

Swift, Jonathan. The Drapier's Letters. The Prose Works of Jonathan Swift. Vol. VI. Ed. Temple Scott. The Project Gutenberg E-Book of the Prose Works of Jonathan Swift, 2004 (1903) [1724]. http://www.gutenberg.org/ebooks/12784 http://www.wattpad.com/15780-the-prose-works-of-jonathan-swift-d-dvolume-06] Web 10 July 2020

Swift, Jonathan. "A Modest Proposal for Preventing the Children of Ireland from being a Burden to their Parents or Country and for making them beneficial to the Publick". Jonathan Swift. "Gulliver's Travels and Other Writings. Ed. Louis Landa. London, Oxford: Oxford University Press, 1976 (1729). 439-446.

Usandizaga, Aránzazu (ed.). 1982. Jonathan Swift. Irish Tracts. La cuestión de Irlanda. Barcelona: Erasmo-Bosch.

Ward, David. Jonathan Swift: An Introductory Essay. London: Methuen, 1973.

Webster's Online Dictionary: http://www.websters-online-dictionary.org/ Web 10 July 2020

Welch, Robert. The Concise Oxford Companion to Irish Literature. Oxford: Oxford University Press, 2000.

West's Encyclopedia of American Law: http://www.lincolnlibraries.org/databases/Wests_Encyclopedia_of_America n_Law.htm Web 10 July 2020

Yale University Office of the Vice President and General Counsel: http://ogc.yale.edu/ [With information about legal issues of general interest]. Web 10 July 2020

\section{Appendix: Corpus of the instances analysed}

1.

I am no inconsiderable shopkeeper in this town, I have discoursed with several of my own and other trades, with many gentlemen both of city and country, and also with great numbers of farmers, cottagers, and labourers, who all agree that two shillings in change for every family would be more than necessary in all dealings. Now by the largest computation (even before that grievous discouragement of agriculture, which hath so much lessened our numbers [6]) the souls in this kingdom are computed to be one million and a half, which, allowing but six to a family, makes two hundred and fifty thousand families, and consequently two shillings to each family will amount only to five and twenty thousand pounds, whereas this honest liberal hardwareman Wood would impose upon us above four times that sum. (Letter II, p. 27).

2. His first proposal is, that "whereas he hath already coined seventeen thousand pounds, and has copper prepared to make it up forty thousand pounds, he will be content to coin no more, unless the EXIGENCES OF TRADE REQUIRE IT, though his patent empowers him to coin a far greater quantity." (Letter II, p. 29).

3. His proposals conclude with perfect high treason. He promises, that no person shall be _obliged_to receive more than fivepence halfpenny of his coin in one payment: By which it is plain, that he pretends to _oblige_every subject in this kingdom to take so much in every payment, if it be offered; whereas his patent obliges no man, nor can the prerogative by law claim such a power, as I have often observed; so that here Mr. Wood takes upon him the entire legislature, and an absolute dominion over the properties of the whole nation (Letter II, page 30). 
4. Perhaps I have been too tedious; but there would never be an end, if I attempted to say all that this melancholy subject will bear. I will conclude with humbly offering one proposal, which, if it were put in practice, would blow up this destructive project at once. Let some skilful judicious pen draw up an advertisement to the following purpose.

That "Whereas one William Wood hardware-man, now or lately sojourning in the city of London, hath, by many misrepresentations, procured a patent for coining an hundred and forty thousand pounds[12] in copper halfpence for this kingdom, which is a sum five times greater than our occasions require. And whereas it is notorious that the said Wood hath coined his halfpence of such base metal and false weight, that they are, at least, six parts in seven below the real value. And whereas we have reason to apprehend, that the said Wood may, at any time hereafter, clandestinely coin as many more halfpence as he pleases. And whereas the said patent neither doth nor can_oblige_ His Majesty's subjects to receive the said halfpence in any payment, but leaves it to their voluntary choice, because, by law the subject cannot be _obliged_to take any money except gold or silver. And whereas, contrary to the letter and meaning of the said patent, the said Wood hath declared that every person shall be _obliged_ to take fivepence halfpenny of his coin in every payment. And whereas the House of Commons and Privy-council have severally addressed his Most Sacred Majesty, representing the ill consequences which the said coinage may have upon this kingdom. And lastly whereas it is universally agreed, that the whole nation to a man (except Mr. Wood and his confederates) are in the utmost apprehensions of the ruinous consequences, that must follow from the said coinage.

Therefore we whose names are underwritten, being persons of considerable estates in this kingdom, and residers therein, do unanimously resolve and declare that we will never receive, one farthing or halfpenny of the said Wood's coining, and that we will direct all our tenants to refuse the said coin from any person whatsoever; Of which that they may not be ignorant, we have sent them a copy of this advertisement, to be read to them by our stewards, receivers, \&c." (Letter II, p. 32-33)

"'And, as to the witnesses, it was a query whether my lord lieutenant by his own power could send them; and, if he have such power, yet it will not be possible to come at the witnesses, for several in each house vouched several facts on their own knowledge, to whom the houses gave credit; my lord lieutenant can neither be apprised of the persons nor of the particulars which the members testified; whereas, if the parliament was sitting, those members would appear, and make good their assertions. (From "Letter from William King, Archbishop of Dublin, to Edward Southwell, Esq., dated the 23d March, 1723. Footnote n.4 to Letter III, p. 47-48)

You will here please to observe, that the profit allowed to Wood by the patent is twelvepence out of every pound of copper valued at_1s. $6 \mathrm{~d}_{\_}$. whereas_5d_only is allowed for coinage of a pound weight for the English halfpence, and this difference is almost 25 _per cent_. which is double to the highest exchange of money, even under all the additional pressures, and obstructions to trade, that this unhappy kingdom lies at present. This one circumstance in the coinage of three hundred and sixty ton of copper makes a difference of twenty-seven thousand seven hundred and twenty pounds between English and Irish halfpence, even allowing those of Wood to be all of the heaviest sort. (Letter III, p.52)

7. The Parliament, who in matters of this nature are the most able and faithful counsellors, did represent this grant to be "destructive of trade, and dangerous to the properties of the people," to which the only answer is, that "the King hath a prerogative to make such a grant."

It is asserted that in the patent to Knox, his "halfpence, are made and declared the current coin of the kingdom," whereas in this to Wood, there is only a "power given to issue them to such as will receive them." The authors of the Report, I think, do not affirm that the King can by law declare_anything_ to be current money by his letters-patents. (Letter III, p. 55)

8. $\quad$ First we desire to know, why His Majesty's prerogative might not have been as well asserted, by passing this patent in Ireland, and subjecting the several conditions of the contract to the inspection of those who are only concerned, as was formerly done in the only precedents for patents granted for coining for this kingdom, since the mixed money[12] in Queen Elizabeth's time, during the difficulties of a rebellion: Whereas now upon the greatest imposition that can possibly be practised, we must go to England with our complaints, where it hath been for some time the fashion to think and to affirm that "we cannot be too hardly used." Again the Report says, that "such patents are obligatory." After long thinking, I am not able to find out what can possibly be meant here by this word _obligatory_. (Letter III, p. 56).

9

But because much weight is laid on the precedents of other patents, for coining copper for Ireland, I will set this matter in as clear a light as I can. Whoever hath read the Report, will be apt to think, that a dozen precedents at least could be produced of copper coined for Ireland, by virtue of patents passed in England, and that the coinage was there too; whereas I am confident, there cannot be one precedent shewn of a patent passed in England for coining copper for Ireland, for above an hundred years past, and if there were any before, it must be in times of confusion. (Letter III, p. 59)

10. "'What argument,'" quotes Monck Mason from the tract issued in 1724 entitled, "A Defence of the Conduct of the People of Ireland, in their unanimous refusal of Mr. Wood's Copper Money," "'can be drawn from the badness of our former coinages but this, that because we have formerly been cheated by our coiners, we ought to suffer Mr. Wood to cheat us over again? 'If any be brought, it is immediately sent away, the two, or as I am informed, the three pence in the ounce, given by the East India Company, being a temptation not to be resisted; but, the truth is, very little is brought in, for the merchants that carry our commodities to foreign markets, find it more to their advantage to carry directly to London whatever they receive in cash; and whereas formerly they used, when they had disposed of their cargo, to load their vessels with such commodities as there was a demand for in Ireland, and bring the rest in cash, they bring now only the commodities, and send the silver to London; and when they have got the twopence in every ounce from the East India Company, the rest serves to answer the returns we are obliged to make to England, for the rents we are obliged to 
pay to noblemen and gentlemen who have estates in Ireland and live in England, and for the pensions, and other occasions which are many; by this means they gain likewise the exchange, which is commonly four or five per cent, better to them than if they sent cash.

"'It is farther to be observed, that 21 shillings, which is the value of a guinea in England, makes in Ireland 22 shillings and 9 pence, whereas a guinea passes for 23 shillings with us, therefore, he who sends silver into England, gains three pence more by it than if he sent guineas; this advantage, though it may seem little, yet in a manner has entirely drained us of our English money which was given in lieu of foreign silver. ([From Footnote 15: "On this subject of the want of small money in Ireland, Monck Mason traverses the Report in the following manner:"]; Letter III, p. 62)

11.

[Footnote 20: So ready was the response to this suggestion of Swift's, that it was found necessary for tradesmen to take precautions to have it publicly known that they were in no way connected with Wood and his money, The following is a copy of an advertisement which illustrates this:

"Whereas several persons in this kingdom suspect that John Molyneux of Meath Street, ironmonger, and his brother Daniel Molyneux, of Essex Street, ironmonger, are interested in the patent obtained by William Wood for coining of halfpence and farthings for this kingdom.

"Now we the said John Molyneux and Daniel Molyneux, in order to satisfy the public, do hereby declare, that we are in no way concerned with the said Wood in relation to his said patent; And that we never were possessed of any of the said halfpence or farthings, except one halfpence and one farthing, which I the said John Molyneux received in a postletter, and which I immediately afterwards delivered to one of the Lords-Justices of Ireland.

"And we do further declare, that we will not directly or indirectly, be anyways concerned with the said Wood's halfpence or farthings; but on the contrary, act to the great advantage and satisfaction of this kingdom, as good, loving and faithful subjects ought to do. And we do further declare, that to the best of our knowledge, the said William Wood is not in this kingdom.

"Given under our hands in Dublin this 22d. day of August 1724.

"JOHN MOLYNEUX

"DAN. MOLYNEUX."

Another ran as follows:

"ADVERTISEMENT.

"Whereas, I, Thomas Handy, of Meath Street, Dublin, did receive by the last packet, from a person in London, to whom I am an entire stranger, bills of lading for eleven casks of Wood's halfpence, shipped at Bristol, and consigned to me by the said person on his own proper account, of which I had not the least notice until I received the said bills of lading.

"Now I, the said Thomas Handy, being highly sensible of the duty and regard which every honest man owes to his country and to his fellow-subjects, do hereby declare, that I will not be concerned, directly or indirectly, in entering, landing, importing, receiving, or uttering any of the said Wood's halfpence, for that I am fully convinced, as well from the addresses of both Houses of Parliament, as otherwise, that the importing and uttering the said halfpence will be destructive to this nation, and prejudicial to his Majesty's revenue.

"And of this my resolution I gave notice by letter to the person who sent me the bills of lading, the very day I received them, and have sent back the said bills to him.

"THO. HANDY. "Dublin, 29th. August, 1724." [T.S.]] (p. 64-65, footnote 20 to Letter III, my italics)

12. And this gives me an opportunity of explaining, to those who are ignorant, another point, which hath often swelled in my breast. Those who come over hither to us from England, and some weak people among ourselves, whenever in discourse we make mention of liberty and property, shake their heads, and tell us, that Ireland is a "depending kingdom," as if they would seem, by this phrase, to intend that the people of Ireland is in some state of slavery or dependence different from those of England; Whereas a "depending kingdom" is a modern term of art, unknown, as I have heard, to all ancient civilians, and writers upon government; and Ireland is on the contrary called in some statutes an "imperial crown," as held only from God; which is as high a style as any kingdom is capable of receiving. (Letter IV, p. 81)

13. The fifth thing to be considered, is, that the members of the grand jury being merchants, and principal shopkeepers, can have no suitable temptation offered them, as a recompense for the mischief they will suffer by letting in this coin, nor can be at any loss or danger by rejecting the bill: They do not expect any employments in the state, to make up in their own private advantage, the destruction of their country. Whereas those who go about to advise, entice, or threaten them to find that bill, have great employments, which they have a mind to keep, or to get greater, which was likewise the case of all those who signed to have the author prosecuted. And therefore it is known, that his grace the Lord Archbishop of Dublin,[1] so renowned for his piety, and wisdom, and love of his country, absolutely refused to condemn the book, or the author. (Seasonable Advice, p. 88)

14. I remember some months ago I was at your house upon a commission, where I am one of the governors: But I went thither not so much on account of the commission, as to ask you some questions concerning Mr. Wood's patent to coin halfpence for Ireland; where you very freely told me, in a mixed company, how much you had been always against that wicked project, which raised in me an esteem for you so far, that I went in a few days to make you a visit, after many years' intermission. I am likewise told, that your son wrote two letters from London, (one of which I have seen) empowering those to whom they were directed, to assure his friends, that whereas there was a malicious report spread of his engaging himself to Mr. Walpole for forty thousand pounds of Wood's coin, to be received in Ireland, the said report was false and groundless. (Letter V, p. 93)

Logos et Littera: Journal of Interdisciplinary Approaches to Text 
15. "We found also that thirty and two old half-pence coined for Ireland in the reigns of King Charles 2d., King James 2d., and King William 3d. and Queen Mary, and produced by Mr. Wood, weighed six ounces and eight pennyweight _Troy, that is, one hundred and three grains and a half apiece one with another. They were much worn, and if about six or seven grains be allowed to each of them one with another for loss of their weight by wearing, the copper-money coined for England, in the reign of King William being already as much lightened by wearing, they might at first weigh about half a pound_avoirdupois_; whereas only thirty of those coined by Mr. Wood are to be of that. They were also made of bad copper, two of those coined in the reign of King Charles II. wasted much in the fire, and then spread thin under the hammer, but not so well without cracking as those of Mr. Wood. Two of those coined in the reign of King James II. wasted much more in the fire, and were not malleable when red hot. Two of those coined in the reign of King William and Queen Mary wasted still more in the fire, and turned to an unmalleable substance like a cinder, as your Lordships may see the pieces now laid before you. (p. 140; From APPENDIX II: REPORT OF THE ASSAY ON WOOD'S COINAGE, MADE BY SIR ISAAC NEWTON, EDWARD SOUTHWELL, ESQ., AND THOMAS SCROOPE, ESQ.[1]).

16.

The King's interest and honour is more concerned in the protection of the innocent, than in the punishment of the guilty, as in all the immediate actions of his Majesty we find that maxim pursued, a maxim can never run a prince into excesses. We do not only find those princes represented in history under odious characters, who have basely betrayed the innocent, but such as by their spies and informers were too inquisitive after the guilty, whereas none was ever blamed for clemency, or for being too gentle interpreters of the law. Though Trajan was an excellent prince, endowed with all heroical virtues; yet the most eloquent writers, and his best friends, found nothing more to be praised in his government, than that in his time, all men might think what they pleased, and every man speak what he thought, this I say, that if any amongst us by violent measures, and a dictatorial behaviour have raised jealousies in the minds of His Majesty's faithful subjects, the blame may lie at their door. (p. 147; From APPENDIX IV: A LETTER FROM A FRIEND TO THE RIGHT HONOURABLE ------[1] Ceteri, quanto quis servitio promptior, opibus et honoribus extollerentur: Invalido legum auxilio, quae vi, ambitu, postremo pecunia turbabantur.--_Tacit. An._ To THE RIGHT HONOURABLE -----)

17. I confess _I_take that to be the meaning of the word counsel, but I am certain that is not_all_that is meant by it, that is what must be understood when it is called the king's counsel, _id est, the counsel or reasons for which the king by his servants, his attorney-general or coroner, has drawn and sent to the grand jury a charge against a subject.

But the counsel of a juror is a different thing, it is the evidence, the motives and reasons that induce him or his fellow-jurors to say_billa vera_or_ignoramus_, and the opinion he or they happen to be of when the question is put by the foreman for finding or not finding: This counsel every man is sworn to keep secret, that so their opinion and advice may not be of prejudice to them hereafter, That as they are sworn to act without favour or affection, so may they also act without FEAR. Whereas, were it otherwise the spirit of revenge is so universal, there are but few cases wherein a juror could act with safety to himself; either the prosecuted, as where the bill is found, or the prosecutor, where it is returned _ignoramus, may contrive to defame the jurors who differ from them in opinion: As I am told has happened to some very honest citizens who are represented to be Jacobites since their opinions were know to be against -.-.. And sometimes revenge or ambition may prompt men to carry it further, as in the case of Mr. Wilmer, who in King Charles $2 \mathrm{~d}$ 's time was very severely handled for being one of an _ignoramus_ jury.---- 'Tis not necessary to say whom he disobliged by being so.----But if I remember right his case was this. (From Appendix IV: A SECOND LETTER FROM A FRIEND TO THE RIGHT HONOURABLE ----- p. 150)

18. APPENDIX V

THE PRESENTMENT OF THE GRAND JURY OF THE COUNTY OF THE CITY OF DUBLIN.[1]

Whereas several great quantities of base metal coined, commonly called_Wood's halfpence,_ have been brought into the port of Dublin, and lodged in several houses of this city, with an intention to make them pass clandestinely, among His Majesty's subjects of this kingdom; notwithstanding the addresses of both houses of parliament and the privy-council, and the declarations of most of the corporations of this city against the said coin; And whereas His Majesty hath been graciously pleased to leave his loyal subjects of this kingdom at liberty to take or refuse the said halfpence. (p. 155)

\section{APPENDIX VI}

PROCLAMATION AGAINST THE DRAPIER.

"_Oct. 27th,_ 1724.

"A proclamation for discovering ye Author of ye Pamphlet intituled A letter to ye whole people of Ireland, by M.B. Drapier, author of the Letter to the Shop-keepers, etc.

$£ 300$ Reward

BY THE LORD-LIEUTENANT AND COUNCIL OF IRELAND.

\section{A Proclamation. \\ "CONTENT:}

"Whereas a wicked and malicious pamphlet, intituled A Letter to the whole people of Ireland, by M.B. Drapier, author of the Letter to the Shop-keepers, etc., printed by John Harding, in Molesworth's Court, in Fishamble Street, Dublin, in which are contained several seditious and scandalous paragraphs highly reflecting upon his Majesty and his Ministers, tending to alienate the affections of his good subjects of England and Ireland from each other, and to promote sedition among the people, hath been lately printed and published in this kingdom: We, the Lord-Lieutenant and Council do hereby publish and declare that, in order to discover the author of the said seditious pamphlet, we will give the necessary orders for the payment of three hundred pounds sterling, to such person or persons as shall within the specified six months from this date hereof, discover the author of the said pamphlet, so as he be apprehended and convicted thereby.

Logos et Littera: Journal of Interdisciplinary Approaches to Text 
"Given at the council chamber in Dublin, this twenty-seventh day of October, one thousand seven hundred and twenty-four.

"(Signed) Midleton_Cancer_. Shannon; Donnerail; G. Fforbes; H. Meath; Santry; Tyrawly; Fferrars; William Conolly; Ralph Gore; William Whitshed; B. Hale; Gust. Hume; Ben Parry; James Tynte; R. Tighe; T. Clutterbuck. (p. 156)

20. IRELAND'S CASE HUMBLY PRESENTED TO THE HONOURABLE THE KNIGHTS, CITIZENS, AND BURGESSES IN PARLIAMENT ASSEMBLED

MOST HUMBLY SHEWETH,

Whereas your Honours finding the late Grant or Letters Patents obtained by Mr. William Wood, for making Three Hundred and Sixty Tun weight of copper half-pence for the Kingdom of Ireland, were to be manufactured in London \&c. which money is now coining in Bristol, and that the said money was to weigh two shillings and sixpence in each pound weight, and that change was to be uttered or passed for all such as were pleased to take the same in this Kingdom. (From APPENDIX VIII, p. 160) 